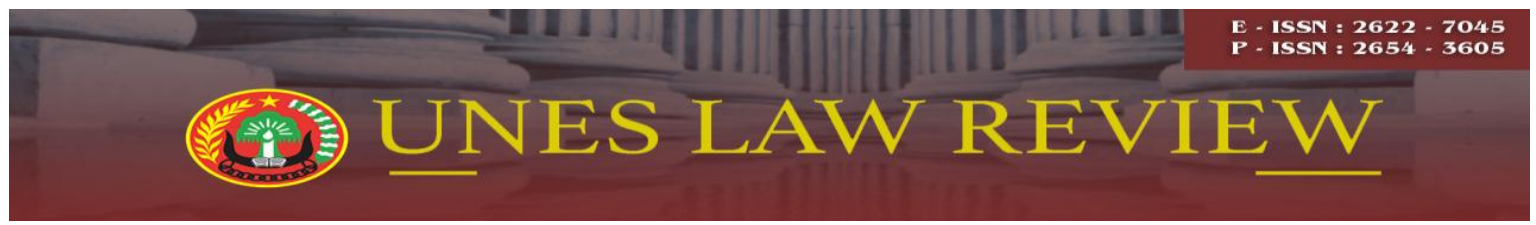

Email: uneslawreview@gmail.com

Online: http://review-unes.com/index.php/law

Volume 2, Issue 3, Maret 2020

\title{
PENGGUNAAN CCTV (CLOSED CIRCUIT TELEVISION) SEBAGAI ALAT BUKTI PETUNJUK DALAM MENGUNGKAP TINDAK PIDANA PENCURIAN KENDARAAN BERMOTOR \\ (Studi Pada Satreskrim Polres Sawahlunto)
}

\author{
Ardiansyah Rolindo Saputra \\ Program Magister Ilmu Hukum, Universitas Ekasakti, Padang, Indonesia \\ Email: ardiansyahrolindosaputra@gmal.com
}

\begin{abstract}
The position of CCTV according to the ITE and RKUHAP Laws is a legitimate evidence, whereas according to the Criminal Procedure Code the position of CCTV is evidence but there is an expansion in the ITE Law article 5 paragraph (2) which states that electronic information or electronic documents or printouts are extensions of evidence which is valid in accordance with the applicable Procedural Law in Indonesia and the position of CCTV in proving a common crime in the trial is evidence, because the KUHAP does not regulate the position of CCTV as evidence. One of the facilities for using CCTV is the disclosure of criminal acts of motor vehicle theft which are very prevalent in the jurisdiction of the Sawahlunto Regional Police Station. This research is a descriptive analytical study. Adapaun the results of research into motor vehicle theft at the Sawahlunto police Satreskrim, there were 264 cases of theft of motorized vehicles that were revealed and recorded through CCTV from 509 criminal acts of motor vehicle theft that were reported at the Satal Police Headquarters in Sawalunto. The use of CCTV helps investigators to uncover who is the perpetrator of the crime of motor vehicle theft with the help of IT experts who understand CCTV. The elements that meet CCTV as evidence are Article 184 paragraph 1 of the Criminal Procedure Code, CCTV footage can be used as evidence of expansion (which is also strengthened by the Constitutional Court Decision No. 20 / PUUXIV / 2016 dated September 7, 2016 and Article 5 of the Law ITE) so that CCTV footage can be used as a panel of judges as a guide to ensure the existence of a criminal act. Second, the constraints faced by Sawahlunto District Police Satreskrim investigators in using CCTV as evidence to reveal the crime of motor vehicle theft are maintaining CCTV in the original state, because after data from CCTV was taken, the video was not clearly visible when playing and brought CCTV experts nor can it be fast.
\end{abstract}

Kata Kunci: CCTV, Alat Bukti, Tindak Pidana Pencurian

\section{PENDAHULUAN}

Perkembangan saat ini pencurian kendaraan bermotor bisa dilihat dengan Closed Circuit Television (CCTV), sebagai bentuk kemajuan teknologi. Pada umumnya rekaman CCTV digunakan sebagai pelengkap sistem keamanan dan banyak dipergunakan di 
berbagai bidang seperti militer, bandara, toko, kantor dan pabrik. Bahkan pada perkembangannya, rekaman CCTV sudah banyak dipergunakan di dalam lingkup rumah pribadi. Perkembangan kriminalitas atau tindak pidana dalam masyarakat yang sedang mengalami modernisasi meliputi masalah-masalah yang berhubungan dengan frekuensi kejahatan, kualitas kejahatan, dan kemungkinan timbulnya jenis-jenis kejahatan atau tindak pidana baru (Kristan dan Yopi Gunawan, 2013:1).

Kecenderungan melakukan pencurian dengan delik apapun, namun dalam beberapa kasus pencurian dilakukan dalam waktu tertentu, yaitu melibatkan kondisi dimana setiap orang akan mencari waktu yang tepat dalam melakukan aksi. Modus Operandinya dari beberapa pengamatan terhadap kasus-kasus tampak bahwa kejadian pencurian yang sangat rawan terhadap perilaku pencurian adalah diwaktu malam hari, sehingga hampir setiap saat diwaktu malam seluruh komponen masyarakat cenderung menyiapkan berbagai cara untuk mengatasi atau meminimalkan peluang pencurian (Suwandy, 2015:4).

Untuk meminimalisir terjadinya tindak pidana pencurian sepeda motor dibantu dengan kemajuan teknologi. Munculnya perkembangan teknologi membuat seseorang melakukan tindak pidana yang secara langsung telah mempengaruhi lahirnya bentuk- bentuk hukum baru. Kehadiran Undang-undang Nomor 11 Tahun 2008 Tentang Informasi Dan Transaksi Elektronik selanjutnya disebut UU ITE sebagai langkah yang tepat untuk mengantisipasi berbagai kemungkinan penyalahgunaan teknologi yang tak terkendali sehingga bisa merugikan orang lain. Pemerintah perlu mendukung perkembangan dan kemajuan teknologi yang sedemikian pesat melalui infrastruktur hukum dan pengaturannya sehingga pemanfaatan teknologi informasi dapat dilakukan secara aman (Parit Purnomo, 2016:67). UU ITE merupakan pembaharuan bagi hukum acara pidana yang berlaku di Indonesia yang dapat memperluas informasi sebagai suatu alat bukti yang sah. Dalam perjalanannya penegakan hukum juga terpengaruh dengan perkembangan ilmu pengetahuan dan teknologi tersebut, salah satunya adalah penerapan teknologi alat perekam video yang memiliki berbagai jenis dan nama, misalnya: Kamera tersembunyi, kamera pengintai, rekaman CCTV, rekaman CCTV Camera, Spy came, video recorder (Roni Alexandro Lahagu, 2017:2).

Rekaman CCTV adalah suatu media yang dapat digunakan untuk memuat rekaman setiap informasi yang dapat dilihat, dibaca dan didengar dengan bantuan sarana rekaman 
CCTV. Rekaman CCTV dijadikan sebagai alat bukti yang sistemnya menggunakan video camera untuk menampilkan dan merekam gambar pada waktu dan tempat tertentu dimana perangkat ini terpasang yang berarti menggunakan signal yang bersifat tertutup, tidak seperti televisi biasa yang merupakan broadcast signal (Efa Laela Fakhriah, 2009:18).

Di wilayah hukum Kepolisian Resor (Polres) Sawahlunto menunjukkan pencurian kendaraan bermotor sangat meningkat. Pada tahun 2016 Satuan Reseserse Kriminal (Satreskrim) Polres Sawahlunto mendapatkan 35 laporan polisi terkait pencurian kendaraan bermotor, sedangkan pada tahun 2017 tingkat pencurian kendaraan bermotor meningkat menjadi 50 laporan polisi, sedangkan sampai bulan April pada tahun 2018 ini Satreskrim Polres Sawahlunto sudah menerima laporan sebanyak 23 pencurian kendaraan bermotor.

Dalam pengungkapan kasus tindak pidana pencurian kendaraan bermotor, Satreskrim Polres Sawahlunto beberapa kali menggunakan CCTV sebagai petunjuk pengungkapan kasus tindak pidana pencurian kendaraan bermotor tersebut. Sehingga penggunaannya dalam mengungkap kejahatan atau sebagai sarana pendukung dalam membuktikan tindak pidana akan berhadapan dengan keabsahannya sebagai alat bukti yang sudah tentu akan berbenturan dengan instrumen hukum yang ada mengingat bahwa pembuktian dalam kasus tindak pidana dengan alat bukti yang digunakan ialah alat bukti rekaman CCTV.

Berdasarkan latar belakang yang telah diuraikan di atas dapat dirumuskan beberapa permasalahan yang akan dibahas dalam penelitian yaitu: Bagaimanakah penggunaan CCTV sebagai alat bukti petunjuk dalam mengungkap tindak pidana pencurian kendaraan bermotor pada Satreskrim Polres Sawahlunto? Apakah kendala yang dihadapi penyidik Satreskrim Polres Sawahlunto dalam penggunaan CCTV sebagai alat bukti petunjuk guna mengungkap tindak pidana pencurian kendaraan bermotor?

\section{METODE PENELITIAN}

Penelitian ini merupakan penelitian deskriptif analitis. Pendekatan yang digunakan dalam penelitian ini adalah pendekatan yuridis normatif yang didukung pendekatan yuridis empiris. Data yang digunakan dalam penelitian ini yaitu data sekunder dan data primer. Terhadap semua data dan bahan yang diperoleh dari hasil penelitian disusun dan dianalisis secara kualitatif, dan disajikan dalam bentuk deskriptif kualitatif. 


\section{HASIL PENELITIAN DAN PEMBAHASAN}

Pelaksana Penggunaan CCTV Sebagai Alat Bukti Petunjuk Dalam Mengungkap Tindak Pidana Pencurian Kendaraan Bermotor Pada Satreskrim Polres Sawahlunto.

Penyidikan adalah serangkaian tindakan penyidik dalam hal dan menurut cara yang diatur dalam undang-undang untuk mencari serta mengumpulkan bukti yang dengan bukti itu membuat terang tentang tindak pidana yang terjadi dan guna menemukan tersangkanya. Selain Pejabat Polisi yang diberi wewenang untuk melakukan penyidikan ada juga Pejabat Pegawai Negeri Sipil tertentu yang diberi wewenang khusus oleh undang-undang. Penyidikan tindak pidana pencurian kendaraan bermotor juga harus memenuhi unsur-unsur yang terdapat dalam rumusan Pasal 362 KUHP yaitu: "Barang siapa mengambil barang sesuatu, yang seluruhnya atau sebagian kepunyaan orang lain, dengan maksud untuk dimiliki secara melawan hukum, diancam karena pencurian, dengan pidana penjara paling lama lima tahun atau denda paling banyak enam puluh rupiah",

Unsur-unsurnya Pasal 362 KUHP sebagai berikut: a). Barang siapa, b). Mengambil barang sesuatu, c). Barang kepunyaan orang lain, d). Dengan maksud untuk dimiliki secara melawan hukum, Pasal 362 KUHP itu terdiri 4 unsur seperti tersebut diatas, tanpa menitik beratkan pada satu unsur. Tiap-tiap unsur mengandung arti yuridis untuk dipakai menentukan atas suatu perbuatan hukum.

Di dalam melakukan tugas dan wewenang penyidik harus selalu bertindak berdasarkan ketentuan perundang-undangan yang berlaku sehingga tidak boleh melakukan penyidikan atas kehendak sendiri saja atau dengan sewenang-wenang dan tidak boleh melanggar hak asasi manusia, sebagaimana yang telah ditentukan di dalam Pasal 1 ayat (1) KUHP yaitu Suatu perbuatan tidak dapat dipidana, kecuali berdasarkan ketentuanketentuan perundang-undangan pidana yang telah ada sebelumnya.

Kedudukan rekaman CCTV sebagai alat bukti yang sah dalam proses tindak pidana berpijak pada Pasal 5 UU ITE merupakan alat bukti hukum yang sah dan keputusan MK Nomor 20/PUU-XIV/2016 tanggal 7 September 2016, yang menyatakan informasi elektronik (termasuk rekaman kamera CCTV) tidak mempunyai kekuatan hukum mengikat sepanjang tidak dimaknai khususnya frasa "Informasi Elektronik dan/atau Dokumen Elektronik" sebagai alat bukti dilakukan dalam rangka penegakan hukum atas permintaan 
kepolisian, kejaksaan, dan/atau institusi penegak hukum lainnya yang ditetapkan berdasarkan undang-undang.

Artinya, rekaman kamera CCTV bisa menjadi alat bukti yang sah apabila dilakukan dalam rangka penegakan hukum atas permintaan kepolisian, kejaksaan, dan/atau institusi penegak hukum lainnya yang ditetapkan berdasarkan undang-undang. Rekaman CCTV merupakan hasil dari perekaman yang dilakukan oleh perangkat CCTV. Perlu diketahui, CCTV tidak hanya terdiri dari kamera dan kabelnya saja, tetapi juga memiliki bagianbagian lain, yaitu Camera, DVR (Digital Video Recorder), Hard Disk Drive (HDD), Coaxial Cable, Power Cable, dan BNC Connector. Dapat diketahui bahwa perangkat CCTV tidak hanya menampilkan apa yang terlihat oleh kamera CCTV tersebut melalui monitor yang tersambung, tetapi juga merekam dan menyimpannya ke dalam media penyimpanan Hard Disk Drive. Data atau informasi yang direkam dan disimpan itulah yang kemudian dinamakan rekaman CCTV.

Agar dapat digunakan sebagai alat bukti, maka rekaman CCTV yang disimpan dalam media penyimpanan hard disk harus diambil atau dipindahkan ke dalam media penyimpanan lain seperti Flashdisk, kemudian biasanya disimpan dalam CD atau media penyimpanan lainnya yang dapat dengan mudah dibawa-bawa, maka rekaman CCTV yang digunakan menjadi alat bukti adalah berupa Dokumen Elektronik.

Alasannnya adalah karena rekaman CCTV tersebut mengandung suatu informasi elektronik yang telah disimpan, diteruskan atau dipindahkan ke dalam media digital yang lain untuk kemudian ditampilkan kembali pada perangkat seperti komputer atau perangkat lain yang dapat membaca rekaman CCTV tersebut. hal ini sesuai dengan pengertian dokumen elektronik dalam Pasal 1 Angka 4 UU ITE.

Pembuktian tindak pidana pencurian kendaraan bermotor ini merupakan proses penting dalam pemeriksaan tersangka terutama terekam dan diungkap melalui CCTV. Melalui pembuktian ini lah ditentukan nasib tersangka, apakah ia bersalah atau tidak. Penyidik harus hati-hati, cermat, dan matang menilai dan mempertimbangkan masalah pembuktian. Pembuktian dalam acara pidana sangat penting karena nantinya akan terungkap kejadian yang sebenarnya berdasarkan berbagai macam alat bukti yang ada dalam persidangan. 
Untuk menilai kekuatan suatu alat bukti, termasuk alat bukti elektronik maka yang menjadi kekuatan utamanya adalah informasi yang terkandung di dalam alat bukti tersebut. Semakin baik kualitas informasinya, maka semakin kuat kejadian-kejadian yang dapat dibuktikan. Oleh karena itu, informasi yang terdapat dalam alat bukti elektronik harus dapat dijamin keasliannya karena akan berdampak pada kualitas informasi yang didapatkan dari alat bukti elektronik tersebut. Bila alat bukti elektronik berisikan informasi yang tidak jelas atau setengah-setengah atau bahkan telah dimanipulasi, maka akan berakibat fatal pada proses pembuktiannya karena tidak lagi berdasar pada fakta-fakta yang sebenarnya. Rekaman CCTV dalam bentuk aslinya atau bentuk originalnya yaitu bentuk video akan lebih memberikan pembuktian yang kuat daripada hasil cetaknya yang hanya berupa potongan-potongan gambar dari video rekaman CCTV tersebut.

Dalam menganalisis data yang ada di CCTV sangat dibutuhkan keterangan ahli. Keterangan ahli digunakan oleh polisi dalam menentukan suatu tindak pidana apakah sudah layak memenuhi unsur-unsur dari perbuatan pidana tersebut yang dutuangkan dalam Berita Acara Perkara.

Sehingga dapat disimpukan oleh penulis penggunaan CCTV sebagai alat bukti berdasarkan: 1) Pemasangan kamera CCTV bukanlah sengaja untuk suatu kasus tertentu, namun CCTV dipasang untuk bisa memantau apa yang terjadi pada suatu tempat umum seperti kafe, bank, mall, jalan raya, ATM, kantor pemerintah, dll. sehingga CCTV tidak harus dibuat oleh pejabat yang berwenang; 2) Rekaman CCTV merupakan alat bukti elektronik yang secara yurisprudensi telah sering digunakan oleh hakim utk mengungkapkan kebenaran fakta dengan melihat kesesuaian antara rekaman CCTV dengan fakta empiris; dan 3) Sesuai dengan KUHAP pasal 184 ayat 1, rekaman CCTV dapat dijadikan sebagai barang bukti perluasan (yang diperkuat juga oleh UU ITE) sehingga rekaman CCTV dapat dijadikan majelis hakim sebagai petunjuk untuk memastikan adanya tindak pidana.

\section{Kendala yang Dihadapi Penyidik Satreskrim Polres Sawahlunto Dalam Penggunaan CCTV Sebagai Alat Bukti Petunjuk Guna Mengungkap Tindak Pidana Pencurian Kendaraan Bermotor}

Pelaksanaan proses penyidikan tentang tindak pidana pencurian kendaraan bermotor roda dua oleh polisi di Kota Sawahlunto belum mencapai hasil yang maksimal, 
karena laporan dan pengaduan oleh masyarakat tentang tindak pidana pencurian kendaraan bermotor roda dua yang masuk di Polres Sawahlunto begitu banyak. Tetapi seluruh tim penyidik selalu berusaha semaksimal mungkin untuk mencari bukti-bukti yang ada di tempat kejadian perkara serta mencari pelakunya.

Dalam melakukan pencarian barang bukti dari hasil tindak pidana pencurian sepeda motor, pelaku pencurian selalu mempunyai cara untuk menghilangkan barang bukti tersebut, seperti kendaraan hasil curian oleh pelaku langsung di larikan ke luar sumbar, membongkar habis semua komponen-komponen motor seperti body motor, mesin motor, dan kerangka motor untuk di jual secara bersamaan ataupun dijual secara terpisah. Hal ini yang membuat penyidik kehilangan barang bukti dari hasil tindak pidana pencurian sepeda motor yang dilakukan oleh pelaku.

Selain itu korban pelaku pencurian kendaraan bermotor tidak segera melaporkan kepada polisi terdekat, sehingga pelaku pencurian dengan mudah menghilangkan barang bukti yang digunakan dalam aksi kejahatannya dan pelaku dengan cepat melarikan diri ke luar sumbar dengan menggunakan kendaraan dari hasil curiannya atau menggunakan alat transportasi lainnya.

Modus baru yang digunakan oleh pencurian kendaraan bermotor roda dua diantaranya yaitu dengan membawa plat nomor yang sesuai dengan STNK yang asli, lalu pelaku mencari jenis motor yang sesuai dengan STNK dan segera mengganti dengan plat nomor yang telah dibawanya. Ada juga dengan menggunakan obat bius sehingga korban yang terkena bius langsung jatuh pingsan dan pelaku dengan segera melarikan motor tersebut.

Barang bukti yang berhasil ditemukan oleh penyidik terhadap pelaku pencurian kendaraan bermotor roda dua adalah seperti kunci " $T$ ", gunting gembok atau gunting rantai, duplikat kunci, obeng, tang, kawat, obat bius, kabel penghubung mesin, dan motor hasil curian.

Kendala yang sering dihadapi oleh penyidik dalam mencari barang bukti yaitu kurangnya informasi dari masyarakat. Informasi dari masyarakat sangatlah penting dalam proses penyidikan sehingga memudahkan penyidik dalam mencari pelaku pencurian kendaraan bermotor roda dua. Pihak kepolisian dengan keterbatasan dan tingkat profesionalnya masing masing berusaha terus mengungkap kasus pencurian sepeda motor 
serta mengembangkan untuk mencari bukti lainnya, namun tidak terlepas dari peran masyarakat dan informan sebagai petunjuk oleh penyidik dalam melakukan pencarian barang bukti tentang tindak pidana pencurian kendaraan bermotor roda dua di Polres Sawahlunto.

Kredit sepeda motor yang sangat ringan membuat masyarakat terlalu mudah untuk mendapatkan sepeda motor. Dengan jumlah pengangguran yang banyak membuat jumlah pelaku pencurian sepeda motor semakin meningkat. Taktik dan teknik penyidik dalam mencari barang bukti hasil tindak pidana pencurian kendaraan bermotor roda dua adalah membuat berita acara pemeriksaan, setelah membuat berita acara pemeriksaan maka penyidik langsung melakukan penyidikan mulai dari awal tempat kejadian perkara sampai mencari informasi dari masyarakat sekitar yang mengetahui.

Setelah mendapatkan informasi, penyidik segera melakukan pengembangan atas informasi yang didapat dari masyarakat. Namun yang menjadi kendala bagi penyidik adalah para pelaku bukan berasal dari sumbar melainkan berasal dari luar sumbar. Biasanya hasil pencurian sepeda motor tersebut langsung dibawa kedaerah yang sepi penduduknya di luar Kota Sawahlunto seperti Daerah Dhamasraya, Solok Selatan, dan Daerah sepi lainnya.

Untuk menghadirkan CCTV, maka CCTV harus dalam Keadaan orisinil, yaitu membiarkan keadaan yang sekarang seperti keadaan yang sebelumnya, dengan kata lain masih dalam keadaan asli. CCTV tidak lepas dari adanya kekurangan dan keterbatasan yang menjadi kendala bagi penyidik dalam mengungkap terjadinya tindak pidana. Kendala yang menjadi masalah berdasarkan hasil peneltian adalah hasil rekaman CCTV telah mengalami editing.

Orisinil ini digunakan dalam pemenuhan unsur alat bukti petunjuk yang kedua mengenai harus adanya kesesuaian antara masing- masing perbuatan, kejadian dan keadaan satu dengan yang lain atau keadaan dengan tindak pidana yang didakwakan. Data hasil rekaman CCTV harus dalam keadaan seperti aslinya guna dapat dilihat bahwa perbuatan tindak pidana itu dapat dibuktikan dengan adanya hasil rekaman CCTV.

Selain itu kendala dari pengungkapan tindak pidana kendaraan pencurian bermotor melalui CCTV ini adalah kesulitan mendatangkan sakasi ahli yang paham tentang CCTV 
secepat mungkin. Karena ahli yang didatangkan harus paham tentang teknologi CCTV dan cara penilaian pembuktian seseorang yang terekam dengan CCTV tersebut.

\section{PENUTUP}

Unsur-unsurnya Pasal 362 KUHP sebagai berikut: a). Barang siapa, b). Mengambil barang sesuatu, c). Barang kepunyaan orang lain, d). Dengan maksud untuk dimiliki secara melawan hukum, Pasal 362 KUHP itu terdiri 4 unsur seperti tersebut diatas, tanpa menitik beratkan pada satu unsur. Tiap-tiap unsur mengandung arti yuridis untuk dipakai menentukan atas suatu perbuatan hukum.

Dalam melakukan pencarian barang bukti dari hasil tindak pidana pencurian sepeda motor, pelaku pencurian selalu mempunyai cara untuk menghilangkan barang bukti tersebut, seperti kendaraan hasil curian oleh pelaku langsung di larikan ke luar sumbar, membongkar habis semua komponen-komponen motor seperti body motor, mesin motor, dan kerangka motor untuk di jual secara bersamaan ataupun dijual secara terpisah. Hal ini yang membuat penyidik kehilangan barang bukti dari hasil tindak pidana pencurian sepeda motor yang dilakukan oleh pelaku.

\section{DAFTAR PUSTAKA}

\section{Buku Taks:}

Efa Laela Fakhriah, Bukti Elektronik Dalam Pembuktian Perdata, Alumni, Bandung, 2009.

Kristan dan Yopi Gunawan, Sekulumit Tentang Penyadapan Dalam Hukum Positif di Indonesia, Nuansa Aulia, Bandung, 2013.

\section{Hasil Penelitian, Wanwancara \& Journal:}

Parit Purnomo, Penerapan Teknologi Alat Perekam Video Sebagai Alat Bukti Dalam Pengungkapan Tindak Pidana (Analisis Yuridis Normatif Putusan Nomor: 71/Pid.B/2012/PN.MGL dan Putusan Nomor 452/PID.B/2011/PN.Sbg), Jurnal Advokasi, Volume 5, Nomor 2, 2016

Roni Alexandro Lahagu, Kedudukan Rekaman CCTV Sebagai Alat Bukti Dalam Tindak Pidana Korupsi Setelah Keluarnya Putusan Mahkamah Konstitusi Nomor 20/PUU-XIV/2016, Jurnal Ilmu Hukum Universitas Sumatera Utara, Desember, 2017.

Suwandy, Tinjauan Yuridis Terhadap Tindak Pidana Pencurian Sepeda Motor Yang Dilakukan Oleh Anak, Tesis, Universitas Hasanudin, Makasar, 2015.

Wawancara dengan Kasat Reskrim Polres Sawahlunto pada tanggal 20 Mei 2019. 


\section{Peraturan Perundang-Undangan:}

Kitab Undang-undang Hukum Perdata;

Keputusan MK Nomor 20/PUU-XIV/2016

Undang-undang Nomor 11 Tahun 2008 Tentang Informasi Dan Transaksi Elektronik 